\title{
Heterologous Expression of the Constitutive Disease Resistance 2 and 8 Genes from Poncirus trifoliata Restored the Hypersensitive Response and Resistance of Arabidopsis cdr1 Mutant to Bacterial Pathogen Pseudomonas syringae
}

\author{
Xiaobao Ying ${ }^{1}(\mathbb{D})$, Bryce Redfern ${ }^{1}$, Frederick G. Gmitter Jr. ${ }^{2}(\mathbb{D})$ and Zhanao Deng ${ }^{1, *(\mathbb{D})}$ \\ 1 Gulf Coast Research and Education Center, IFAS, University of Florida, 14625 County Road 672, \\ Wimauma, FL 33598, USA; yingxb75@ufl.edu (X.Y.); killerblr@ufl.edu (B.R.) \\ 2 Citrus Research and Education Center, IFAS, University of Florida, 700 Experiment Station Road, \\ Lake Alfred, FL 33850,USA; fgmitter@ufl.edu \\ * Correspondence: zdeng@ufl.edu
}

Received: 1 June 2020; Accepted: 29 June 2020; Published: 30 June 2020

check for updates

\begin{abstract}
Huanglongbing (HLB), also known as citrus greening, is the most destructive disease of citrus worldwide. In the United States, this disease is associated with a phloem-restricted bacterium, Candidatus Liberibacter asiaticus. Commercial citrus cultivars are susceptible to HLB, but Poncirus trifoliata, a close relative of Citrus, is highly tolerant of HLB. Isolating P. trifoliata gene(s) controlling its HLB tolerance followed by expressing the gene(s) in citrus is considered a potential cisgenic approach to engineering citrus for tolerance to HLB. Previous gene expression studies indicated that the constitutive disease resistance (CDR) genes in P. trifoliata (PtCDRs) may play a vital role in its HLB tolerance. This study was designed to use Arabidopsis mutants as a model system to confirm the function of PtCDRs in plant disease resistance. PtCDR2 and PtCDR 8 were amplified from $P$. trifoliata cDNA and transferred into the Arabidopsis cdr1 mutant, whose resident CDR1 gene was disrupted by T-DNA insertion. The PtCDR2 and PtCDR8 transgenic Arabidopsis cdr1 mutant restored its hypersensitive response to the bacterial pathogen Pseudomonas syringae pv. tomato strain DC3000 (Pst DC3000) expressing avrRpt2. The defense marker gene PATHOGENESIS RELATED 1 (PR1) expressed at much higher levels in the PtCDR2 or PtCDR8 transgenic $c d r 1$ mutant than in the non-transgenic $c d r 1$ mutant with or without pathogen infection. Multiplication of Pst DC3000 bacteria in Arabidopsis was inhibited by the expression of PtCDR2 and PtCDR8. Our results showed that PtCDR2 and PtCDR8 were functional in Arabidopsis and played a positive role in disease resistance and demonstrated that Arabidopsis mutants can be a useful alternate system for screening Poncirus genes before making the time-consuming effort to transfer them into citrus, a perennial woody plant that is highly recalcitrant for Agrobacterium or biolistic-mediated transformation.
\end{abstract}

Keywords: Huanglongbing; disease resistance; cisgenics; genetic engineering; Poncirus; Arabidopsis

\section{Introduction}

Huanglongbing (HLB), also known as citrus greening, is the most destructive disease in citrus worldwide. The typical symptoms of HLB include asymmetrical blotchy yellowing or mottling on leaves and yellowing of leaf veins. As the disease progresses, citrus fruit become lopsided and smaller, and diseased mature fruit remain partially green. Eventually, the infected trees die [1]. HLB is associated with the phloem-restricted gram-negative bacteria Candidatus Liberibacter spp. that can be transmitted 
by insect vectors or grafting [2]. In the United States (U.S.), the presumptive pathogen of HLB is Candidatus Liberibacter asiaticus (Clas), and the insect vector of CLas is Asian citrus psyllid (ACP) (Diaphorina citri). The outbreak of HLB in Florida has resulted in a $72.2 \%$ reduction in citrus juice production and a 20.5\% reduction in fresh market fruit in the U.S. from 2007-2008 to 2017-2018 [3]. This disease has been responsible for substantial increases in the costs of citrus grove maintenance and management [4]. The great majority of commercial citrus cultivars are highly susceptible to HLB [5]. The pathogen has not been cultured, and the virulence mechanisms of CLas remain largely unknown. Nevertheless, several reports have shown that CLas encodes effectors to inhibit citrus plant defense and development [6-13].

Management of HLB has been a lofty challenge, although a wide range of management techniques have been tested, ranging from the frequent application of insecticides in an attempt to suppress the psyllid vector, enclosing individual citrus trees in ACP-proof nets to prevent them from contact with infectious psyllids [14] to planting new citrus trees inside ACP-proof screen houses and the application of antibiotics to citrus trees. So far, the primary techniques used by Florida growers for managing HLB under field conditions have been applying insecticides to suppress the population of ACP [15] and modifying nutrient management strategies to reduce HLB symptoms and improve fruit yield and quality [16-19]. These management practices have been extremely costly, making them an unsustainable endeavor. With the citrus production in Florida alone being a $\$ 9$ billion industry, it is vital to find more effective, economic, and sustainable management strategies to curb the devastation caused by this disease [20].

The development and use of HLB-resistant/tolerant cultivars is considered the best long-term management strategy for this bacterial disease. Toward finding HLB resistance/tolerance, numerous citrus cultivars, close relatives, and distant citrus relatives have been screened under natural disease pressure and ACP presence or by artificial CLas inoculation. Within the genus Citrus, a number of commercial cultivars with HLB tolerance were identified, including 'LB-9' Sugar Belle ${ }^{\circledR}$ mandarin, 'Temple' tangor, rough lemon, etc. [21-25]. A number of rootstock cultivars resulting from crosses between Citrus and Poncirus showed strong tolerance to HLB [26-28]. Several distant citrus relatives were found having strong resistance to HLB [14,29]. In these evaluations, sweet orange, grapefruit, and most mandarins, citrus of the most important commercial value to the industry, were highly sensitive to HLB. Sweet orange, grapefruit, and mandarin cultivars with strong tolerance, ideally resistance, to HLB are much needed.

To increase citrus tolerance or resistance to HLB, a number of foreign or synthetic genes have been introduced into citrus and have shown some promising results. For example, thionin, belonging to the pathogenesis-related 13 family [30], overexpressed in citrus resulted in increased resistance to HLB and citrus canker [31]. Another antimicrobial peptide, cecropin B, was expressed in citrus phloem and reduced HLB severity in the transgenic citrus [32]. The master regulator gene of plant defense, NPR1 from Arabidopsis, was transferred into citrus, and the transgenic plants showed enhanced resistance to HLB [33]. Although these transgenic approaches can be a powerful tool to develop HLB resistance/tolerance, commercialization and export of transgenic citrus fruit and processed citrus products may encounter marketplace resistance because of negative public perception and anti-GMO sentiments.

To make engineered HLB resistant/tolerant citrus cultivars more acceptable to citrus consumers and producers, cisgenic approaches seem worthy of exploration. Cisgenic approaches have been pursued in a number of crops, and cisgenic apple lines with resistance to several diseases have been developed [34,35]. Consumer surveys indicated that cisgenic products were evidently more acceptable to consumers than transgenic products [36]. Recently, the U.S. Department of Agriculture (USDA) Animal and Plant Health Inspection Service (APHIS) issued new rules and regulations governing the movement, including environmental release, of certain genetically engineered (GE) organisms (https://www.aphis.usda.gov/brs/fedregister/BRS_2020518.pdf). Under these new rules, GE plants can be exempted from regulation if the genetic modification in the plants introduces a gene known to occur 
in the plant's gene pool. As these new rules and regulations become effective in 2020, citrus cultivars with genetically engineered HLB resistance from cisgenic approaches may become commercialized more readily than before in the U.S. It should be pointed out that at this time, regulatory bodies in other countries have not differentiated cisgenic from transgenic plants.

Numerous efforts have been made to understand the tolerance mechanisms of citrus with regards to HLB. Basal resistance was considered to play an important role in the tolerance of some citrus to HLB, as shown by analyzing the transcriptional profiles of two closely related HLB-tolerant 'Jackson' grapefruit-like hybrid trees and HLB-susceptible 'Marsh' grapefruit trees [37]. HLB-tolerant rough lemon showed a stronger and faster response to CLas infection at earlier stages than susceptible sweet orange [22]. The constitutive disease resistance 1 (CDR1) has been implicated in HLB tolerance in some studies [28]. This gene was induced in HLB-susceptible 'Cleopatra' mandarin, but the basal expression level of CDR1 was much higher in the HLB-tolerant citrus rootstock cultivar 'US-897' than in 'Cleopatra' mandarin [28]. Constitutive overexpression of CDR1 in Arabidopsis resulted in activation of its defense genes and enhanced plant disease resistance [38]. Arabidopsis CDR1 is an extracellular aspartic protease with the conserved catalytic sequence motifs DTG and DSG [39]. The optimized condition for CDR1 activity is a pH of 6.0-6.5 in a dimerized state [40]. Salicylic acid (SA) was required in CDR1-mediated disease resistance [28]. Expression of the CDR1 gene in rice (OsCDR1) was activated upon treatment with SA [41]. Overexpression of OsCDR1 in Arabidopsis and rice conferred enhanced resistance against bacterial and fungal pathogens [41]. The function of OsCDR1 in disease resistance was found to be dependent on its proteinase activity [41,42].

Poncirus trifoliata is a close relative of Citrus [43] and has been the most important source of disease resistance genes for citrus breeding and genetic improvement. Several studies have shown that $P$. trifoliata and its hybrids with Citrus are highly tolerant to HLB [14,44]. It was found that the constitutive disease resistance 2 and constitutive disease resistance 8 from P. trifoliata (PtCDR2/PtCDR8) were upregulated upon CLas infection [45]. If these genes could confer citrus resistance/tolerance to HLB, they could be used in a cisgenic approach to produce HLB-resistant/tolerant citrus cultivars that may be more acceptable to citrus consumers and producers. In this study, PtCDR2/PtCDR8 were cloned and transferred into the Arabidopsis cdr1 mutant. PtCDR2/PtCDR8 transgenic Arabidopsis cdr1 lines showed a typical hypersensitive response (HR) to Pseudomonas syringae pv. tomato strain DC3000 (Pst DC3000) expressing avrRpt2 (Pst DC3000 avrRpt2), a model pathogen widely used to test Arabidopsis plants for disease resistance. Expression of PtCDR2 and PtCDR8 in Arabidopsis cdr1 lines inhibited growth of Pst DC3000 avrRpt2. Our results showed that Arabidopsis mutants could be used to screen genes from Poncirus (and Citrus) for their roles in plant disease resistance before extensive studies in Citrus. Using Arabidopsis mutants as an alternate system may help identify candidate genes for engineering citrus for HLB tolerance/resistance.

\section{Results}

\subsection{Cloning and Structure of Constitutive Disease Resistance 2 and 8 from Poncirus trifoliata}

PtCDR2 and PtCDR8 were amplified from cDNA synthesized from mRNAs isolated from mature leaves of $P$. trifoliata. The deduced PtCDR2 and PtCDR8 proteins both contain 428 amino acid residues and share $94.2 \%$ identity. PtCDR2 and PtCDR8 were aligned with predicted CDR1 proteins from sweet orange (Citrus sinensis) (CsCDR1 XP_006484735), Clementine mandarin (Citrus clementina) (CcCDR1 XP_006437356), pummelo (Citrus maxima) (Cg6g008160.1), citron (Citrus medica) (Cm260950.1), 'Mangshan' mandarin (Citrus reticulata) (MSYJ114420.1), Chinese box orange (Atalantia buxifolia) (sb29852.1), and Arabidopsis (AtCDR1 AY243479). Two conserved domains (DTGS and DSGT) were found in these deduced proteins (Figure 1A). PtCDR2 and PtCDR8 fell into the same clade in the phylogenetic tree (Figure 1B). 
A

\begin{tabular}{|c|c|}
\hline CcCDR1 & - TEILAVADTGSDLIWTQCEPRP --- DIIIDSGTTLTLLPQRY --- \\
\hline Cg6g008160.1 & - TEILAVADTGSDLIWTQCEPCP --- DIVIDSGTTLTLLPQGY"-- \\
\hline $\mathrm{Cm} 260950.1$ & --- TEILAVADTGSDLIWTQCEPCP --- GI \\
\hline $\mathrm{CsCDR} 1$ & LIWTQCEPCP--- G \\
\hline MSYJ114420.1 & SDLIWTQCEPCP--- D \\
\hline PtCDR2 & GSDLIWTQCEPCP --- DI \\
\hline PtCDR8 & DSGTTLTLLPQRY--- \\
\hline SB29852.1 & --- TEILAVADTGSDLIWTQCEPCP --- GIVIDSGTTLTLLPQGY־-- \\
\hline ItCDR1 & LWWTQCAPCD--- NII \\
\hline
\end{tabular}

B

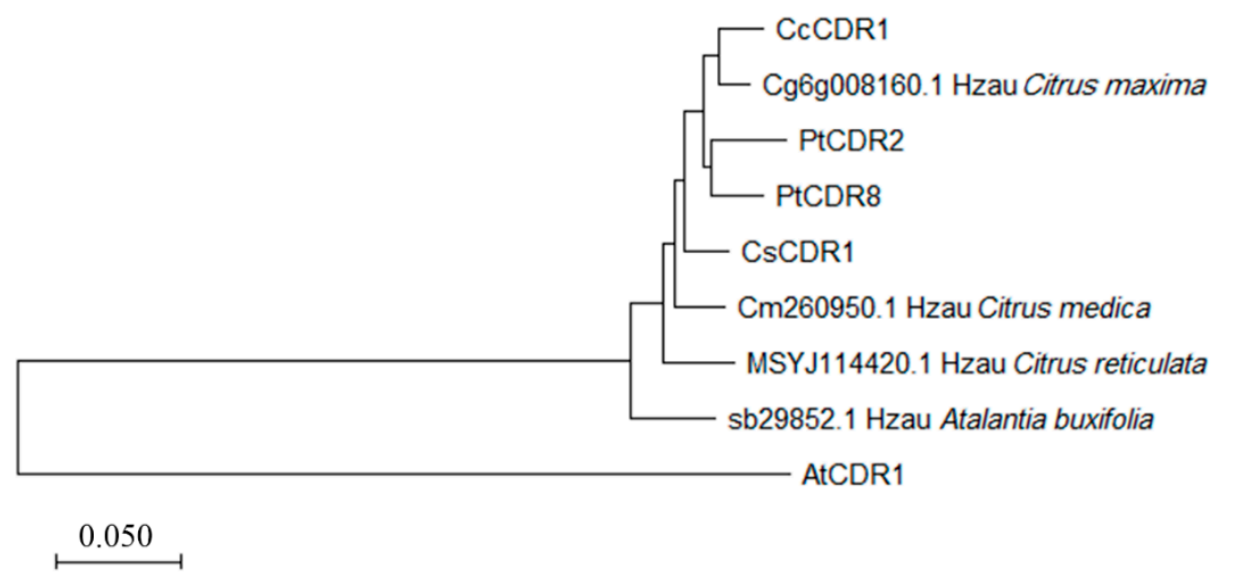

Figure 1. Bioinformatical analysis of PtCDR2 and PtCDR8 with CDR1s from other citrus and Arabidopsis. (A) Two conserved catalytic motifs were present in PtCDR2, PtCDR8, and CDR1s from Arabidopsis (AtCDR1), Citrus maxima (Cg6g008160.1), Citrus medica (Cm260950.1), Citrus reticulata (MSYJ114420.1), Atalantia buxifolia (sb29852.1), Citrus sinensis (CsCDR1), and Citrus clementina (CcCDR1). The sequences of the two conserved catalytic motifs were DTGS (in the blue box) and DSGT (in the light green box). The sequences were aligned with ClustalW. (B) Phylogenetic tree was generated by the neighbor-joining method using MEGA X.

\subsection{PtCDR2 and PtCDR8 Restored the Hypersensitive Response of Arabidopsis cdr1 Mutant to Pathogen}

To test whether PtCDR2 and PtCDR8 can function as CDR1 in disease resistance, an Arabidopsis cdr1 mutant resulting from T-DNA insertion [46] was transformed with PtCDR2 and PtCDR8 separately. Multiple T0 transgenic lines were obtained for each gene. These T0 lines were selfed, and multiple T1 transgenic lines were produced. T1 transgenic lines were inoculated with the bacterial pathogen Pst DC3000 avrRpt2 at OD 0.0001. The mutant Arabidopsis $c d r 1$ did not show any HR at 3 days post inoculation or infiltration (DPI) with Pst DC3000 avrRpt2. On the contrary, wild-type Arabidopsis (Col-0) showed a typical HR. Twelve PtCDR2 transgenic $c d r 1$ mutant lines and fourteen PtCDR8 transgenic $c d r 1$ mutant lines showed the same type of HR as the wild-type Arabidopsis. For each Poncirus gene, two transgenic Arabidopsis lines were selected randomly to record HR on the infiltrated leaves (Figure 2) and to perform subsequent analyses. 


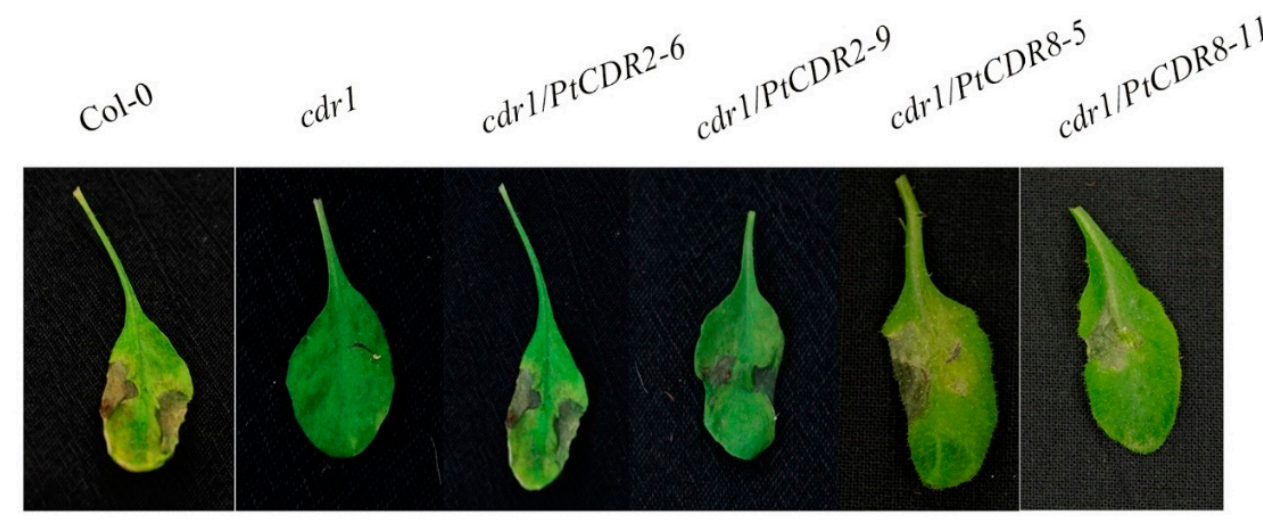

Figure 2. PtCDR2 and PtCDR8 restored hypersensitive response. Wild-type Arabidopsis Col-0, cdr1 mutant, $P t C D R 2$ transgenic $c d r 1$ line 6/line 9, and PtCDR8 transgenic $c d r 1$ line 5/line 11 were infiltrated with Pseudomonas syringae pv. tomato strain DC3000 (Pst DC3000) expressing avrRpt2. Cell death or hypersensitive response (HR) was not observed in the infiltrated area of leaves of the $c d r 1$ mutant; wild-type Arabidopsis, PtCDR2 transgenic cdr1 lines, and PtCDR8 transgenic $c d r 1$ lines all showed cell death or HR in the infiltrated leaf area.

\subsection{PtCDR2 and PtCDR8 Inhibited Pst DC3000 avrRpt2 Growth}

At 3 DPI with Pst DC3000 avrRpt2, six leaf disks were randomly collected from each Arabidopsis plant for bacterial counting. On average, the bacterial count in the wild-type Arabidopsis was 6.3-fold less than the bacterial count in the $c d r 1$ mutant (Figure 3). Bacterial counts in PtCDR 8 transgenic lines 5 and 11 (cdr1/PtCDR8-5 and cdr1/PtCDR8-11) were similar to the bacterial count in the wild-type Arabidopsis and reduced by 6.86- and 6.67-fold, respectively, compared to the bacterial count in the $c d r 1$ mutant. PtCDR2 transgenic lines 6 and 9 (cdr1/PtCDR2-6 and cdr1/PtCDR2-9) showed stronger bacterial growth inhibition: bacterial counts in these lines were reduced by 8.0 - and 15.0 -fold, respectively, compared to the bacterial count in the $c d r 1$ mutant (Figure 3).

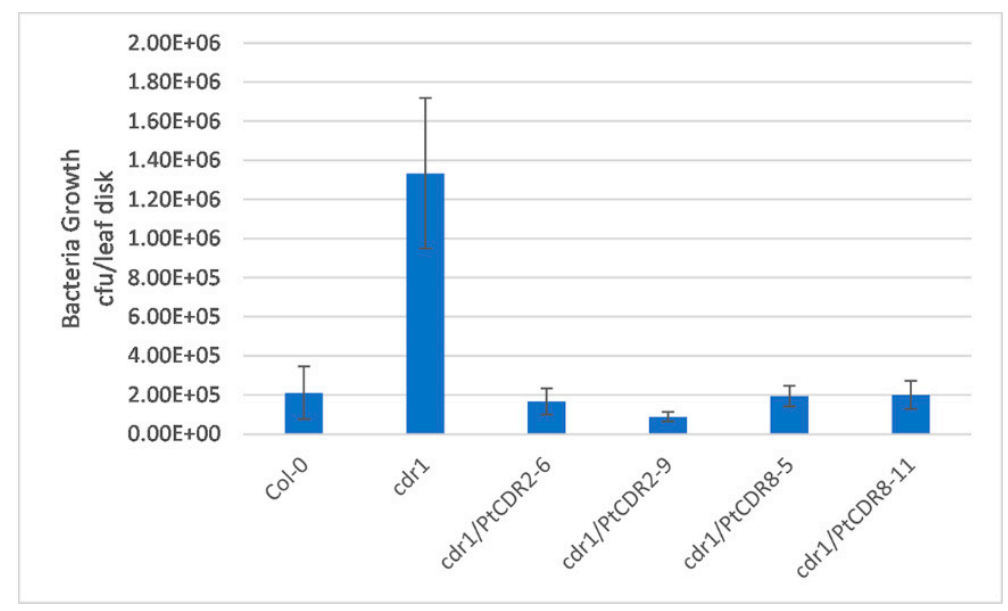

Figure 3. Bacteria growth assay. Twenty-five-day-old Arabidopsis plants were inoculated with Pseudomonas syringae pv. tomato strain DC3000 (Pst DC3000) expressing avrRpt2 by spraying a bacterial cell suspension. Six leaf disks from each plant were collected randomly at 3 DPI, and bacterial cells were extracted and plated out on a solid selective medium containing two antibiotics. Inoculated plants were wild-type Arabidopsis (Col-0), cdr1 mutant (cdr1), and four transgenic cdr1 lines (cdr1/PtCDR2-6, cdr1/PtCDR2-9, cdr1/PtCDR8-5, and cdr1/PtCDR8-11) 


\subsection{PtCDR2 and PtCDR8 Increased the Expression Level of PATHOGENESIS RELATED 1 (PR1) in the} cdr1 Mutant

Overexpression of OsCDR1 in Arabidopsis led to the upregulation of PR1 [41], a marker gene in the SA pathway [47]. The PR1 relative expression level was analyzed among different transgenic lines 3 DPI with Pst DC3000 avrRpt2. Arabidopsis plants in the control were sprayed with a $10 \mathrm{mM}$ $\mathrm{MgCl}_{2}$ solution containing $0.02 \%$ Silwet L-77. PR1 expressed at a lower level in the $c d r 1$ mutant than in the wild-type Arabidopsis (Col-0) (0.38-fold) without inoculation of the pathogen (Figure 4A). $P R 1$ expressed slightly higher in transgenic PtCDR2 lines 6 and 9 (1.66- and 1.47-fold, respectively) but much higher in PtCDR8 transgenic lines 5 and 11 (8.86- and 10.99-fold, respectively) (Figure 4A). At 3 DPI, PR1 expression level was much higher in all genotypes, including the wild type, the $c d r 1$ mutant, and the four transgenic lines (Figure 4B), suggesting that inoculation with Pst DC3000 avrRpt2 induced PR1 expression in all genotypes. At this time, PR1 expression in the $c d r 1$ mutant was still the lowest and lower than its expression in the wild-type Arabidopsis. Different levels of $P R 1$ upregulation were observed in the transgenic lines: PtCDR2 line 9 showed the greatest PR1 upregulation, from 1.47 at 0 DPI to 104.24 at 3 DPI, followed by PtCDR 8 lines 5 and 11 (from 8.66 or 10.99 at 0 DPI to 78.75 or 77.22 at 3 DPI), and PtCDR2 line 6 (from 1.66 at 0 DPI to 43.12 at 3 DPI) (Figure $4 \mathrm{~B}$ ).
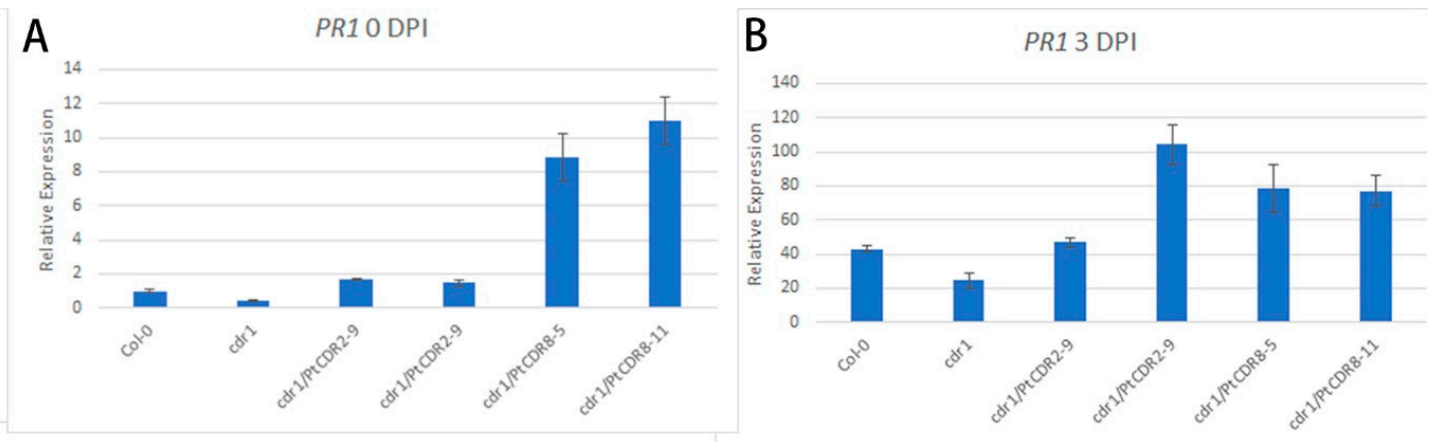

Figure 4. Relative expression of PR1 in wild-type Arabidopsis (Col-0), its cdr1 mutant (cdr1), and four transgenic lines (cdr1/PtCDR2-6, cdr1/PtCDR2-9, cdr1/PtCDR8-5, and cdr1/PtCDR8-11). Relative expression of $P R 1$ was determined using the $2^{-\Delta \Delta C T}$ method. (A) Plants were sprayed with Pseudomonas syringae pv. tomato strain DC3000 (Pst DC3000) expressing avrRpt2 at an $\mathrm{OD}_{600} 0 \mathrm{Of} 0.001$ in $10 \mathrm{mM} \mathrm{MgCl}_{2}$ and $0.02 \%$ Silwet. Leaf samples were collected at 0 and 3 DPI and total RNA was isolated for quantitative real-time PCR analysis. (B) Control plants were sprayed with $10 \mathrm{mM} \mathrm{MgCl}_{2}$ and $0.02 \%$ Silwet.

\section{Discussion}

Previous gene expression and genetic mapping studies have indicated that multiple genes could be involved in certain Poncirus and Citrus cultivars' resistance/tolerance to HLB [22,28,43,48], but so far very few of these candidate genes have been screened and investigated in depth for their actual roles in HLB resistance/tolerance. The primary impediments leading to the lack of progress in candidate gene screening and gene function confirmation are the existence of substantial difficulties in the production of transgenic citrus plants for these candidate genes, inoculation of the transgenic plants with CLas, and collection of reliable CLas bacterial titers and HLB symptom severity scores from the inoculated transgenic plants. Alternate systems are much needed to circumvent some of these challenges and to screen multiple candidate genes to identify the best ones for use in engineering citrus for HLB resistance. Facing similar difficulties with studying CLas in citrus, plant pathologists have made use of the model plant Nicotiana benthamiana to express candidate CLas effector genes and understand their roles in CLas pathogenesis [6]. Recently, Nicotiana benthamiana was also experimentally infected with CLas via dodder transmission and used to identify a critical CLas effector Las $\Delta 5315$ and determine its role in the development of prominent HLB symptoms, including starch accumulation and leaf chlorosis [49]. 
Previously, the garden flower periwinkle (Catharanthus roseus) was infected with CLas, and the infected periwinkle was used to screen antibiotics and various other chemical compounds for controlling or suppressing CLas in planta [50]. We considered using Nicotiana benthamiana and periwinkle for testing the potential role of PtCDR2 and PtCDR8 in plant disease resistance. Nicotiana benthamiana can be readily transformed by co-cultivation of leaf discs with Agrobacterium, and transgenic lines can be inoculated with CLas via dodder transmission [49]. However, information was not available regarding Nicotiana benthamiana resident CDR1 or CDR1-like genes, and desired cdr1 mutants were not available. Periwinkle is extremely difficult to transform with Agrobacterium, and no information was available about its resident CDR1 or CDR1-like genes either. This situation prompted us to explore the use of Arabidopsis mutants as an alternate system to test PtCDR2 and PtCDR 8 and to determine if they would function in Arabidopsis and play any role in disease resistance.

Our results described above clearly showed that both PtCDR2 and PtCDR8 restored the function of Arabidopsis CDR1 and conferred the $c d r 1$ mutant HR and resistance to the bacterial pathogen Pst DC3000 expressing avrRpt2. Our study indicated that Arabidopsis mutants could serve as a useful proxy for screening candidate genes and confirming their role in disease resistance. Using proper Arabidopsis mutants may offer a number of advantages for screening candidate disease resistance and defense genes, as shown in this study. Foreign genes can be readily introduced into Arabidopsis mutants by simple floral dip procedures. Sufficient numbers of homozygous transgenic lines could be produced within several months by selfing T0 transgenic plants. More importantly, a huge collection of Arabidopsis mutants, including numerous mutants with their resident disease resistance and defense genes disrupted, are readily available for use in both forward and reverse genetic studies [51]. Arabidopsis mutants have especially helped formulate the concept of the plant immune system and reveal various plant disease immunity signaling pathways and key genetic factors in these pathways [52]. This study may represent the first effort in using Arabidopsis mutants to screen Poncirus genes for their potential roles in disease resistance. Our study demonstrated the value of Arabidopsis mutants in such an effort. We believe that these mutants may play even more important roles in future citrus genetic studies toward identifying candidate genes for engineering citrus for HLB resistance when CLas cultures become available.

Our results showed that PtCDR2 and PtCDR8 induced significant upregulation of PR1 after pathogen inoculation. The induced $P R 1$ upregulation may indicate the potential value of expressing PtCDR2 and PtCDR8 for enhancing HLB resistance in citrus. PR1 is an inducible marker gene for the SA-mediated plant defense system and plays key roles in plant systemic acquired resistance (SAR) to diseases. In a recent study in citrus, the level of PR1 expression in transgenic sweet orange cultivars 'Hamlin' and 'Valencia' was directly co-related to the Arabidopsis NPR1-mediated resistance to HLB, whereas the expression of the transgene AtNPR1 itself in citrus was not directly co-related to HLB resistance [33]. A similar phenomenon was observed in rice and Arabidopsis transformed with rice CDR1 (OsCDR1): OsCDR1-enhanced disease resistance in transgenic rice and Arabidopsis was also correlated with the induction of PR1 [41]. Based on the observed relationship between PR1 expression and enhanced disease resistance, especially HLB resistance in AtNPR1-transgenic sweet orange, it seems reasonable to speculate that overexpression of PtCDR2 and PtCDR8 may result in similar upregulation of PR1 in transgenic sweet orange and, thus, similarly enhanced HLB resistance. On the other hand, PtCDR2 and PtCDR8 are predicted to be extracellular proteins, like OsCDR1 [41]. This may raise a question: How could PtCDR2 and PtCDR8 as predicted extracellular proteins impart citrus resistance/tolerance to CLas, a bacterial pathogen residing inside citrus phloem elements? Considering these aspects, we speculate that the functioning of PtCDR2 and PtCDR8 may involve some intriguing pathways or pathway components to activate the plant defense system. It has been hypothesized that OsCDR1 activation can lead to the generation of an endogenous extracellular peptide elicitor, and the released elicitor can rapidly activate basal local and systemic defense responses $[40,41]$. To answer these questions in citrus, we initiated an effort to introduce these genes into sweet orange and produce transgenic lines. The transgenic sweet orange lines will be inoculated with CLas to determine their resistance to HLB. 
Overexpression of OsCDR1 in rice resulted in enhanced resistance to Xanthomonas oryzae and Magnaporthe oryzae, the bacterial pathogen of rice blight and the fungal pathogen of rice blast [41]. Overexpression of the same gene in Arabidopsis led to increased resistance against infection by bacterial pathogen Pst DC3000 and fungal pathogen Hyaloperonospora arabidopsidis but not against the necrotrophic pathogen Alternaria brassicicola [41]. These previous studies seem to indicate potential of using PtCDR2 and/or PtCDR8 for engineering resistance to multiple pathogens. In citrus, the bacterial pathogen Xanthomonas citri ssp. citri (Xcc) causes citrus canker, a disease that is important and also difficult to control [53]. Natural genetic resistance to Xcc is rare in citrus. Transgenic resistance to Xcc has been pursued for many years [54,55]. It will be very interesting to find out if PtCDR2 and PtCDR8 transgenic sweet orange will have increased resistance to Xcc.

In summary, we have shown that Arabidopsis mutants (in this case, the $c d r 1$ mutant) can serve as a useful alternate system for screening Poncirus (and Citrus) genes for their roles in plant defense and that PtCDR2 and PtCDR8 both are functional genes and play a key role in plant defense responses. These genes may serve as strong candidate genes for engineering citrus for disease resistance, including resistance to HLB, the deadliest bacterial disease of citrus worldwide.

\section{Materials and Methods}

\subsection{Plant Materials}

The Poncirus trifoliata plants (accession DPI 50-7) were kept in a greenhouse with natural light. Arabidopsis plants were grown in a growth room with a $16 \mathrm{~h} \mathrm{light} / 8 \mathrm{~h}$ dark cycle at $21^{\circ} \mathrm{C}$. The $c d r 1$ mutant (stock number SALK_050514) and wild-type Arabidopsis Col-0 (stock number CS70000) were purchased from TAIR.

\subsection{Sequence Analysis}

Protein sequence alignment and phylogenetic analysis were performed with the software Mega $X$ [56]. The neighbor-joining method was used to generate a phylogenetic tree. The protein sequences of AtCDR1, CsCDR1, and CcCDR1 were retrieved from NCBI [57,58]; other CDRs from Citrus maxima (Cg6g008160.1), Citrus medica (Cm260950.1), Citrus reticulata (MSYJ114420.1), and Atalantia buxifolia (sb29852.1) were retrieved from the Citrus sinensis annotation project [59].

\subsection{Gene Cloning, Construction of Expression Vectors, and Transformation of Arabidopsis cdr1 Mutant}

Mature leaves were collected from $P$. trifoliata plants grown in containers in the greenhouse. Total RNA was extracted from the leaves using the RNeasy plant mini kit (Qiagen, Cat. 74904). RNAs were reverse transcribed to cDNA using the SuperScript ${ }^{\mathrm{TM}}$ III First-Strand Synthesis System (Thermofisher Scientific, Cat. 18080051) and oligo(dT). PtCDR2 and PtCDR8 were amplified with Phusion ${ }^{\circledR}$ High-Fidelity DNA Polymerase (NEB, Cat. M0530S) and primers PtCDR F (CCCGGGATGGCAACCTTCTTGAGTTGTGC) and PtCDR2 R (GAGCTCCAAAATTTAATTACAGCTTGGTGC) or PtCDR $\mathrm{F}$ and PtCDR8 $\mathrm{R}$ (GAGCTCGCTTCCCAATTAATTATTGCTTGGTGC). The amplified DNA fragments were purified after treatment with Taq polymerase and cloned into the pGEM-T Easy vector (Promega, Cat. A1360). The plasmid containing PtCDR2 or PtCDR8 was digested with XmaI and SacI, and then the PtCDR2 and PtCDR8 fragments were cloned into the expression vector pCAMBIA1300-221 [60]. PtCDR2 and PtCDR8 were driven by the CaMV $35 S$ promoter and terminated by the Nos terminator. These expression vectors were then introduced into the Agrobacterium tumefaciens strain EHA105 by electroporation. The Arabidopsis $c d r 1$ mutant was transformed by floral dip [61]. T0 transgenic seeds were selected on MS plates containing kanamycin $(50 \mathrm{mg} / \mathrm{L})$ and hygromycin $(20 \mathrm{mg} / \mathrm{L})$. The positive seedlings were transplanted into soil for disease assay. 


\subsection{Disease Assay}

The model pathogen Pseudomonas syringae pv. tomato strain DC3000 (Pst DC3000) expressing avrRpt 2 was used in this research. Bacteria were cultured at $28^{\circ} \mathrm{C}$ on a shaker in the King's B medium containing two antibiotics, rifampin $(20 \mathrm{mg} / \mathrm{L})$ and kanamycin $(50 \mathrm{mg} / \mathrm{L})$. When the optical density $\left(\mathrm{OD}_{600}\right)$ of the bacterial culture reached 0.6 , bacterial cells were harvested by centrifugation and resuspended in a $10 \mathrm{mM} \mathrm{MgCl}_{2}$ solution. The fifth to seventh rosette leaves of 25-day-old Arabidopsis plants were infiltrated with Pst DC3000 avrRpt2 at an $\mathrm{OD}_{600}$ of $0.0001\left(5 \times 10^{4} \mathrm{CFU} / \mathrm{mL}\right)$ using a $1 \mathrm{~mL}$ needleless syringe. The inoculated leaves were photographed at 3 DPI. For the bacterial growth assay, the 25-day-old Arabidopsis plants were sprayed with a Pst DC3000 avrRpt2 bacterial suspension at an $\mathrm{OD}_{600}$ of $0.001\left(5 \times 10^{5} \mathrm{CFU} / \mathrm{mL}\right)$ and containing $0.02 \%$ Silwet L-77. Six leaf disks were randomly collected from six plants of each genotype with a core borer (6 $\mathrm{mm}$ in diameter). The leaf disks were ground, and the ground tissues were diluted serially by an increment of 10 and plated on solid King's B medium containing rifampin $(20 \mathrm{mg} / \mathrm{L})$ and kanamycin $(50 \mathrm{mg} / \mathrm{L})$. The plates were incubated at $28^{\circ} \mathrm{C}$ in the dark for two days before bacterial colonies were counted.

\subsection{Gene Expression Analysis}

The rosette leaves of Arabidopsis were collected three days after the plants were spray-inoculated with a Pst DC3000 bacterial suspension. RNAs were extracted from the collected Arabidopsis leaf samples using an RNeasy Plant Mini kit (Qiagen, Cat. 74904), following the manual exactly. A High-Capacity RNA-to-cDNA ${ }^{\mathrm{TM}}$ Kit (ThermoFisher Scientific, Cat. 4387406) was used for reverse transcription according to the manufacturer's instruction. Quantitative real-time PCR was performed using PowerUp ${ }^{\text {TM }}$ SYBR ${ }^{\text {TM }}$ Green Master Mix (ThermoFisher Scientific, Cat. A25742) and the QuantStudio 5 real-time PCR system (ThermoFisher Scientific) according to the manufacturer's specifications. The Actin 2 gene was used as the internal reference, and it was amplified with a forward primer 5' - GATCTCCAAGGCCGAGTATG-3' and a reverse primer 5' - CCCCAGCTTTTTAAGCCTTTG-3' . Defense marker gene PR1 was analyzed with primers PR1F 5'-CTCATACACTCTGGTGGG-3' and PR1R 5' - ATTGCACGTGTTCGCAGC-3'. The relative expression of PR1 was calculated using the $2^{-\Delta \Delta C T}$ method [62].

Author Contributions: X.Y. cloned the genes from Poncirus trifoliata, constructed expression vectors, produced transgenic Arabidopsis plants, conducted disease assays, analyzed gene expression, and drafted the manuscript. B.R. assisted in plant transformation and edited the manuscript. Z.D. supervised the research and critically revised the manuscript. F.G.G.J. secured funding, participated in experimental designing, and critically revised the manuscript. All authors have read and agreed to the published version of the manuscript.

Funding: This research was funded by the United States Department of Agriculture/National Institute of Food and Agriculture (USDA/NIFA) Specialty Crop Research Initiative (SCRI) Citrus Disease Research and Extension Program (CDRE), grant number 2014-10119.

Acknowledgments: We thank Zhonglin Mou for providing Pseudomonas syringae pv. tomato strain DC3000 (Pst DC3000) expressing avrRpt2, Dean Gabriel for sharing the plasmid pBI221, and Vladimir Orbovic for sharing the Agrobacterium tumefaciens strain EHA105.

Conflicts of Interest: The authors declare no conflict of interests.

\section{References}

1. Bové, J.M. Huanglongbing: A destructive, newly-emerging, century-old disease of citrus. J. Plant Pathol. 2006, 88, 7-37.

2. Bové, J.M. Huanglongbing or yellow shoot, a disease of Gondwanan origin: Will it destroy citrus worldwide? Phytoparasitica 2014, 42, 579-583. [CrossRef]

3. Dala-Paula, B.M.; Plotto, A.; Bai, J.; Manthey, J.A.; Baldwin, E.A.; Ferrarezi, R.S.; Gloria, M.B.A. Effect of Huanglongbing or greening disease on orange juice quality, a review. Front. Plant Sci. 2018, 9, 1976. [CrossRef] 
4. Spreen, T.H.; Baldwin, J.P.; Futch, S.H. An economic assessment of the impact of Huanglongbing on citrus tree plantings in Florida. HortScience 2014, 49, 1052-1055. [CrossRef]

5. Gottwald, T.R. Current epidemiological understanding of citrus Huanglongbing. Annu. Rev. Phytopathol. 2010, 48, 119-139. [CrossRef]

6. Li, J.Y.; Pang, Z.Q.; Trivedi, P.; Zhou, X.F.; Ying, X.B.; Jia, H.G.; Wang, N.A. 'Candidatus Liberibacter asiaticus' encodes a functional salicylic acid (SA) hydroxylase that degrades SA to suppress plant defenses. Mol. Plant Microbe Interact. 2017, 30, 620-630. [CrossRef]

7. Ying, X.; Wan, M.; Hu, L.; Zhang, J.; Li, H.; Lv, D. Identification of the virulence factors of Candidatus liberibacter asiaticus via heterologous expression in Nicotiana benthamiana using tobacco mosaic virus. Int. J. Mol. Sci. 2019, 20, 5575. [CrossRef]

8. Jain, M.; Fleites, L.A.; Gabriel, D.W. Prophage-encoded peroxidase in 'Candidatus liberibacter asiaticus' is a secreted effector that suppresses plant defenses. Mol. Plant Microbe Interact. 2015, 28, 1330-1337. [CrossRef]

9. Li, H.; Ying, X.; Shang, L.; Redfern, B.; Kypraios, N.; Xie, X.; Xu, F.; Wang, S.; Zhang, J.; Jian, H.; et al. Heterologous expression of clibasia_03915/clibasia_04250 by tobacco mosaic virus resulted in phloem necrosis in the senescent leaves of Nicotiana benthamiana. Int. J. Mol. Sci. 2020, 21, 1414. [CrossRef]

10. Pitino, M.; Armstrong, C.M.; Cano, L.M.; Duan, Y.P. Transient expression of Candidatus Liberibacter Asiaticus effector induces cell death in Nicotiana benthamiana. Front. Plant Sci. 2016, 7. [CrossRef]

11. Clark, K.; Franco, J.Y.; Schwizer, S.; Pang, Z.; Hawara, E.; Liebrand, T.W.H.; Pagliaccia, D.; Zeng, L.; Gurung, F.B.; Wang, P.; et al. An effector from the Huanglongbing-associated pathogen targets citrus proteases. Nat. Commun. 2018, 9, 1718. [CrossRef] [PubMed]

12. Liu, X.; Fan, Y.; Zhang, C.; Dai, M.; Wang, X.; Li, W. Nuclear import of a secreted "Candidatus Liberibacter asiaticus" protein is temperature dependent and contributes to pathogenicity in Nicotiana benthamiana. Front. Microbiol. 2019, 10, 1684. [CrossRef] [PubMed]

13. Zhang, C.; Wang, X.F.; Liu, X.L.; Fan, Y.Y.; Zhang, Y.Q.; Zhou, X.P.; Li, W.M. A novel 'Candidatus Liberibacter asiaticus'-encoded sec-dependent secretory protein suppresses programmed cell death in Nicotiana benthamiana. Int. J. Mol. Sci. 2019, 20, 5802. [CrossRef] [PubMed]

14. Ramadugu, C.; Keremane, M.L.; Halbert, S.E.; Duan, Y.P.; Roose, M.L.; Stover, E.; Lee, R.F. Long-term field evaluation reveals Huanglongbing resistance in Citrus relatives. Plant Dis. 2016, 100, 1858-1869. [CrossRef] [PubMed]

15. Boina, D.R.; Bloomquist, J.R. Chemical control of the Asian citrus psyllid and of Huanglongbing disease in citrus. Pest Manag. Sci. 2015, 71, 808-823. [CrossRef] [PubMed]

16. Zhao, H.; Sun, R.; Albrecht, U.; Padmanabhan, C.; Wang, A.; Coffey, M.D.; Girke, T.; Wang, Z.; Close, T.J.; Roose, M.; et al. Small RNA profiling reveals phosphorus deficiency as a contributing factor in symptom expression for citrus Huanglongbing disease. Mol. Plant 2013, 6, 301-310. [CrossRef]

17. Hu, J.; Jiang, J.; Wang, N. Control of citrus Huanglongbing via trunk injection of plant defense activators and antibiotics. Phytopathology 2018, 108, 186-195. [CrossRef]

18. Hoffman, M.T.; Doud, M.S.; Williams, L.; Zhang, M.Q.; Ding, F.; Stover, E.; Hall, D.; Zhang, S.; Jones, L.; Gooch, M.; et al. Heat treatment eliminates 'Candidatus Liberibacter asiaticus' from infected citrus trees under controlled conditions. Phytopathology 2013, 103, 15-22. [CrossRef]

19. Doud, M.M.; Wang, Y.; Hoffman, M.T.; Latza, C.L.; Luo, W.; Armstrong, C.M.; Gottwald, T.R.; Dai, L.; Luo, F.; Duan, Y. Solar thermotherapy reduces the titer of Candidatus Liberibacter asiaticus and enhances canopy growth by altering gene expression profiles in HLB-affected citrus plants. Hortic. Res. 2017, 4, 17054. [CrossRef]

20. Citrus Statistics. Available online: http://flcitrusmutual.com/citrus-101/citrusstatistics.aspx (accessed on 1 December 2019).

21. Deng, H.H.; Achor, D.; Exteberria, E.; Yu, Q.B.; Du, D.L.; Stanton, D.; Liang, G.; Gmitter, F.G. Phloem regeneration is a mechanism for Huanglongbing-tolerance of "Bearss" lemon and "LB8-9" Sugar Belle®mandarin. Front. Plant Sci. 2019, 10. [CrossRef]

22. Fan, J.; Chen, C.; Yu, Q.; Khalaf, A.; Achor, D.S.; Brlansky, R.H.; Moore, G.A.; Li, Z.G.; Gmitter, F.G., Jr. Comparative transcriptional and anatomical analyses of tolerant rough lemon and susceptible sweet orange in response to 'Candidatus Liberibacter asiaticus' infection. Mol. Plant Microbe Interact. 2012, 25, 1396-1407. [CrossRef] 
23. Stover, E.; McCollum, G. Incidence and severity of Huanglongbing and Candidatus Liberibacter asiaticus titer among field-infected citrus cultivars. HortScience 2011, 46, 1344. [CrossRef]

24. Stover, E.; Inch, S.; Richardson, M.L.; Hall, D.G. Conventional citrus of some scion/rootstock combinations show field tolerance under high Huanglongbing disease pressure. HortScience 2016, 51, 127. [CrossRef]

25. Killiny, N. Metabolite signature of the phloem sap of fourteen citrus varieties with different degrees of tolerance to Candidatus Liberibacter asiaticus. Physiol. Mol. Plant Pathol. 2017, 97, 20-29. [CrossRef]

26. Folimonova, S.Y.; Robertson, C.J.; Garnsey, S.M.; Gowda, S.; Dawson, W.O. Examination of the responses of different genotypes of citrus to Huanglongbing (citrus greening) under different conditions. Phytopathology 2009, 99, 1346-1354. [CrossRef] [PubMed]

27. Albrecht, U.; Bowman, K.D. Tolerance of trifoliate citrus rootstock hybrids to Candidatus Liberibacter asiaticus. Sci. Hortic. 2012, 147, 71-80. [CrossRef]

28. Albrecht, U.; Bowman, K.D. Transcriptional response of susceptible and tolerant citrus to infection with Candidatus Liberibacter asiaticus. Plant Sci. 2012, 185-186, 118-130. [CrossRef]

29. Miles, G.P.; Stover, E.; Ramadugu, C.; Keremane, M.L.; Lee, R.F. Apparent tolerance to Huanglongbing in citrus and citrus-related germplasm. HortScience 2017, 52, 31. [CrossRef]

30. Sels, J.; Mathys, J.; De Coninck, B.M.; Cammue, B.P.; De Bolle, M.F. Plant pathogenesis-related (PR) proteins: A focus on PR peptides. Plant Physiol. Biochem. 2008, 46, 941-950. [CrossRef]

31. Hao, G.; Stover, E.; Gupta, G. Overexpression of a modified plant thionin enhances disease resistance to citrus canker and Huanglongbing (HLB). Front. Plant Sci. 2016, 7, 1078. [CrossRef]

32. Zou, X.; Jiang, X.; Xu, L.; Lei, T.; Peng, A.; He, Y.; Yao, L.; Chen, S. Transgenic citrus expressing synthesized cecropin B genes in the phloem exhibits decreased susceptibility to Huanglongbing. Plant Mol. Biol. 2017, 93, 341-353. [CrossRef] [PubMed]

33. Dutt, M.; Barthe, G.; Irey, M.; Grosser, J. Transgenic citrus expressing an Arabidopsis NPR1 gene exhibit enhanced resistance against Huanglongbing (HLB.; Citrus Greening). PLoS ONE 2015, 10, e0137134. [CrossRef] [PubMed]

34. Kost, T.D.; Gessler, C.; Jansch, M.; Flachowsky, H.; Patocchi, A.; Broggini, G.A. Development of the first cisgenic apple with increased resistance to fire blight. PLoS ONE 2015, 10, e0143980. [CrossRef]

35. Vanblaere, T.; Szankowski, I.; Schaart, J.; Schouten, H.; Flachowsky, H.; Broggini, G.A.; Gessler, C. The development of a cisgenic apple plant. J. Biotechnol. 2011, 154, 304-311. [CrossRef]

36. Edenbrandt, A.K.; Gamborg, C.; Thorsen, B.J. Consumers' preferences for bread: Transgenic, cisgenic, organic or pesticide-free? J. Agric. Econ. 2018, 69, 121-141. [CrossRef]

37. Wang, Y.; Zhou, L.; Yu, X.; Stover, E.; Luo, F.; Duan, Y. Transcriptome Profiling of Huanglongbing (HLB) Tolerant and susceptible citrus plants reveals the role of basal resistance in HLB tolerance. Front. Plant Sci. 2016, 7, 933. [CrossRef]

38. Simoes, I.; Faro, R.; Bur, D.; Faro, C. Characterization of recombinant CDR1, an Arabidopsis aspartic proteinase involved in disease resistance. J. Biol. Chem. 2007, 282, 31358-31365. [CrossRef]

39. Simoes, I.; Faro, C. Structure and function of plant aspartic proteinases. Eur. J. Biochem. 2004, 271, $2067-2075$. [CrossRef]

40. Xia, Y.; Suzuki, H.; Borevitz, J.; Blount, J.; Guo, Z.; Patel, K.; Dixon, R.A.; Lamb, C. An extracellular aspartic protease functions in Arabidopsis disease resistance signaling. EMBO J. 2004, 23, 980-988. [CrossRef]

41. Prasad, B.D.; Creissen, G.; Lamb, C.; Chattoo, B.B. Overexpression of rice (Oryza sativa L.) OsCDR1 leads to constitutive activation of defense responses in rice and Arabidopsis. Mol. Plant Microbe Interact. 2009, 22, 1635-1644. [CrossRef]

42. Prasad, B.D.; Creissen, G.; Lamb, C.; Chattoo, B.B. Heterologous expression and characterization of recombinant OsCDR1, a rice aspartic proteinase involved in disease resistance. Protein Expr. Purif. 2010, 72, 169-174. [CrossRef] [PubMed]

43. Huang, M.; Roose, M.L.; Yu, Q.; Du, D.; Yu, Y.; Zhang, Y.; Deng, Z.; Stover, E.; Gmitter, F.G., Jr. Construction of high-density genetic maps and detection of QTLs associated with Huanglongbing tolerance in citrus. Front. Plant Sci. 2018, 9, 1694. [CrossRef] [PubMed]

44. Boava, L.P.; Cristofani-Yaly, M.; Machado, M.A. Physiologic, anatomic, and gene expression changes in Citrus sunki, Poncirus trifoliata, and their hybrids after 'Candidatus Liberibacter asiaticus' infection. Phytopathology 2017, 107, 590-599. [CrossRef] [PubMed] 
45. Rawat, N.; Kumar, B.; Albrecht, U.; Du, D.; Huang, M.; Yu, Q.; Zhang, Y.; Duan, Y.P.; Bowman, K.D.; Gmitter, F.G., Jr.; et al. Genome resequencing and transcriptome profiling reveal structural diversity and expression patterns of constitutive disease resistance genes in Huanglongbing-tolerant Poncirus trifoliata and its hybrids. Hortic. Res. 2017, 4, 17064. [CrossRef] [PubMed]

46. Alonso, J.M.; Stepanova, A.N.; Leisse, T.J.; Kim, C.J.; Chen, H.; Shinn, P.; Stevenson, D.K.; Zimmerman, J.; Barajas, P.; Cheuk, R.; et al. Genome-wide insertional mutagenesis of Arabidopsis thaliana. Science 2003, 301, 653-657. [CrossRef]

47. Ali, S.; Ganai, B.A.; Kamili, A.N.; Bhat, A.A.; Mir, Z.A.; Bhat, J.A.; Tyagi, A.; Islam, S.T.; Mushtaq, M.; Yadav, P.; et al. Pathogenesis-related proteins and peptides as promising tools for engineering plants with multiple stress tolerance. Microbiol. Res. 2018, 212-213, 29-37. [CrossRef]

48. Yu, Q.; Chen, C.; Du, D.; Huang, M.; Yao, J.; Yu, F.; Brlansky, R.H.; Gmitter, F.G. Reprogramming of a defense signaling pathway in rough lemon and sweet orange is a critical element of the early response to 'Candidatus Liberibacter asiaticus'. Hortic. Res. 2017, 4, 17063. [CrossRef]

49. Pitino, M.; Allen, V.; Duan, Y. Las $\Delta 5315$ effector induces extreme starch accumulation and chlorosis as $C a$. Liberibacter asiaticus infection in Nicotiana benthamiana. Front. Plant Sci. 2018, 9, 113. [CrossRef] [PubMed]

50. Zhang, M.; Duan, Y.; Zhou, L.; Turechek, W.W.; Stover, E.; Powell, C.A. Screening molecules for control of citrus Huanglongbing using an optimized regeneration system for 'Candidatus Liberibacter asiaticus'-infected periwinkle (Catharanthus roseus) cuttings. Phytopathology 2010, 100, 239-245. [CrossRef]

51. Piquerez, S.J.; Harvey, S.E.; Beynon, J.L.; Ntoukakis, V. Improving crop disease resistance: Lessons from research on Arabidopsis and tomato. Front. Plant Sci. 2014, 5, 671. [CrossRef]

52. Jones, J.D.; Dangl, J.L. The plant immune system. Nature 2006, 444, 323-329. [CrossRef] [PubMed]

53. Ference, C.M.; Gochez, A.M.; Behlau, F.; Wang, N.; Graham, J.H.; Jones, J.B. Recent advances in the understanding of Xanthomonas citri ssp. citri pathogenesis and citrus canker disease management. Mol. Plant Pathol. 2018, 19, 1302-1318. [CrossRef] [PubMed]

54. Omar, A.A.; Murata, M.M.; El-Shamy, H.A.; Graham, J.H.; Grosser, J.W. Enhanced resistance to citrus canker in transgenic mandarin expressing Xa21 from rice. Transgenic Res. 2018, 27, 179-191. [CrossRef] [PubMed]

55. Zhang, X.; Francis, M.I.; Dawson, W.O.; Graham, J.H.; Orbovic, V.; Triplett, E.W.; Mou, Z. Over-expression of the Arabidopsis NPR1 gene in citrus increases resistance to citrus canker. Eur. J. Plant Pathol. 2010, 128, 91-100. [CrossRef]

56. Kumar, S.; Stecher, G.; Li, M.; Knyaz, C.; Tamura, K. MEGA X: Molecular evolutionary genetics analysis across computing platforms. Mol. Biol. Evol. 2018, 35, 1547-1549. [CrossRef]

57. Wu, G.A.; Prochnik, S.; Jenkins, J.; Salse, J.; Hellsten, U.; Murat, F.; Perrier, X.; Ruiz, M.; Scalabrin, S.; Terol, J.; et al. Sequencing of diverse mandarin, pummelo and orange genomes reveals complex history of admixture during citrus domestication. Nat. Biotech. 2014, 32, 656-662. [CrossRef]

58. Xu, Q.; Chen, L.L.; Ruan, X.; Chen, D.; Zhu, A.; Chen, C.; Bertrand, D.; Jiao, W.B.; Hao, B.H.; Lyon, M.P.; et al. The draft genome of sweet orange (Citrus sinensis). Nat. Genet. 2013, 45, 59-66. [CrossRef]

59. Wang, X.; Xu, Y.; Zhang, S.; Cao, L.; Huang, Y.; Cheng, J.; Wu, G.; Tian, S.; Chen, C.; Liu, Y.; et al. Genomic analyses of primitive, wild and cultivated citrus provide insights into asexual reproduction. Nat. Genet. 2017, 49, 765-772. [CrossRef]

60. Ying, X.B.; Dong, L.; Zhu, H.; Duan, C.G.; Du, Q.S.; Lv, D.Q.; Fang, Y.Y.; Garcia, J.A.; Fang, R.X.; Guo, H.S. RNA-dependent RNA polymerase 1 from Nicotiana tabacum suppresses RNA silencing and enhances viral infection in Nicotiana benthamiana. Plant Cell 2010, 22, 1358-1372. [CrossRef]

61. Clough, S.J.; Bent, A.F. Floral dip: A simplified method for Agrobacterium-mediated transformation of Arabidopsis thaliana. Plant J. 1998, 16, 735-743. [CrossRef]

62. Livak, K.J.; Schmittgen, T.D. Analysis of relative gene expression data using real-time quantitative PCR and the 2(T)(-Delta Delta C) method. Methods 2001, 25, 402-408. [CrossRef] [PubMed]

(C) 2020 by the authors. Licensee MDPI, Basel, Switzerland. This article is an open access article distributed under the terms and conditions of the Creative Commons Attribution (CC BY) license (http://creativecommons.org/licenses/by/4.0/). 